Abstracta Iranica

Revue bibliographique pour le domaine irano-aryen

Volume 34-35-36 | 2017

Comptes rendus des publications de 2011-2013

\title{
Shai Secunda. The Iranian Talmud. Reading the Bavli in Its Sasanian Context
}

Christelle Jullien

\section{OpenEdition}

1 Journals

Édition électronique

URL : http://journals.openedition.org/abstractairanica/41268

DOI : $10.4000 /$ abstractairanica. 41268

ISSN : 1961-960X

Éditeur :

CNRS (UMR 7528 Mondes iraniens et indiens), Éditions de l'IFRI

Référence électronique

Christelle Jullien, « Shai Secunda. The Iranian Talmud. Reading the Bavli in Its Sasanian Context », Abstracta Iranica [En ligne], Volume 34-35-36 | 2017, document 1, mis en ligne le 15 juillet 2016, consulté le 05 octobre 2020. URL : http://journals.openedition.org/abstractairanica/41268; DOI : https://doi.org/10.4000/abstractairanica.41268

Ce document a été généré automatiquement le 5 octobre 2020.

Tous droits réservés 


\title{
Shai Secunda. The Iranian Talmud. Reading the Bavli in Its Sasanian Context
}

\author{
Christelle Jullien
}

\section{RÉFÉRENCE}

Shai Secunda. The Iranian Talmud. Reading the Bavli in Its Sasanian Context. Philadelphia, University of Pennsylvania Press, 2013, 272 p. (Divinations: Rereading Late Ancient Religion series)

1 Cet ouvrage offre une étude approfondie et originale sur la rédaction du Tamud de Babylone dans le contexte des relations entretenues par les rabbis avec les communautés religieuses et ethniques de l'empire sassanide, spécialement les mazdéens : comment les juifs les ont-il perçus, quels sont les héritages partagés, quelle influence la littérature moyen-perse a-t-elle eu sur l'écriture du Talmud, etc. L'A. met en évidence la manière dont des éléments culturels propres à la société sassanide, et $a$ priori extérieurs au discours rabbinique, ont pu pénétrer les modes de mise par écrit au sein du judaïsme babylonien, spécialement certaines formes discursives élaborées à partir de la rhétorique des prêtres zoroastriens. Comme le souhaite l'A., cette étude veut ainsi ouvrir la voie à de nouvelles recherches "irano-talmudiques" fondées sur l'examen et l'analyse comparée des textes issus du judaïsme et de la littérature moyenperse. 


\section{AUTEURS}

\section{CHRISTELLE JULLIEN}

CNRS, Mondes iranien et indien, Paris 